\title{
Women's empowerment, collective actions, and sustainable fisheries: lessons from Mexico
}

\author{
Jorge Torre ${ }^{1}$ (1) - Arturo Hernandez-Velasco ${ }^{1}$ • Francisco Fernandez Rivera-Melo ${ }^{1}$. Jaime Lopez ${ }^{1}$. \\ Maria Jose Espinosa-Romero ${ }^{1}$
}

Received: 29 April 2019 / Accepted: 22 September 2019/Published online: 24 October 2019

(C) The Author(s) 2019

\begin{abstract}
Collective action is recognized as a key element to successfully implementing sustainable fisheries. Nevertheless, gender equality, as an essential component in such actions, is often missing. In fisheries, women's contributions are regularly invisible and remain unrepresented in statistics. In this paper, we examine the current status of women in Mexican fisheries based on governmental reports and programs, as well as five case studies from small-scale fishing communities. In practice, the government's attempts at increasing participation and leadership of women in fisheries have been varied. This article documents how women's roles are changing when collective actions are implemented to increase fisheries sustainability. Women as cooperative leaders, collaborative decision-makers, and entrepreneurs have become active promoters of good practices, including (1) fishery and ecosystem restoration, (2) environmental monitoring, and (3) marine conservation. Through these actions, women are also empowered in different ways. They have acquired resources (e.g., knowledge, opportunities) and decision-making power, facilitating project developments (e.g., research, cooperatives) that promote fisheries sustainability. Here, we highlight elements that contribute toward empowering women in small-scale fisheries in these five contexts, with applicability elsewhere. These elements include access to role models, such as female scientists leading environmental monitoring; the support of civil society organizations; and a willingness, by men and women, to learn and change the status quo.
\end{abstract}

Keywords Gender relationships and equality $\cdot$ Sustainable fisheries $\cdot$ Marine conservation

"It is our (women's) time to show others how to fish and protect our seas for our grandchildren, the time of our husbands is over"1

\section{Introduction}

The Food and Agriculture Organization of the United Nations emphasizes in their Voluntary Guidelines for Small-Scale Fisheries (FAO 2015) that gender equality

\footnotetext{
${ }^{1}$ Fisherwomen during a panel organized by the Fisheries and Aquaculture Senate Commission (Mexico), January 2016 (Espinosa-Romero et al. 2017).

Jorge Torre

jtorre@ cobi.org.mx

1 Comunidad y Biodiversidad, A.C., Isla del Peruano 215, Col. Lomas de Miramar, 85448 Guaymas, Sonora, Mexico
}

is crucial to the sustainability of small-scale fisheries. In addition, collective action, whereby a group of individuals acting together to achieve a common objective, has been identified as a key tool in promoting sustainable fisheries approaches that seek both human well-being and ecosystem health (FAO 2014; Kalikoski and Franz 2013). Nevertheless, by excluding women from decision-making processes, we are often missing a significant component of collective action despite their important contributions to fishery activities (FAO 2014; Harper et al. 2017; Kleiber et al. 2017). According to the FAO (2014), up to $90 \%$ of fish processing is done by women. In some Pacific Islands, women are responsible for over $50 \%$ of small-scale fisheries catches (Harper et al. 2013). Globally, an estimated 260 million people are involved in marine fisheries when considering both primary and secondary sector activities (Teh and Sumaila 2013), and other estimates suggest that $47 \%$ of fishery workers worldwide are women, when post-harvest activities are included (World Bank 2012). 
However, the contributions of women to fisheries are mostly unrepresented in official statistics and are thus invisible (Branch and Kleiber 2017; Harper et al. 2017; Frangoudes and Gerrard 2018). Women are only recognized as helping or supporting men's fishing activities (Kleiber et al. 2015, 2017), even when women fish, lead, and participate in closely related activities (Frangoudes and Gerrard 2018). In general, women and gender equality are underrepresented across natural resources sectors, research, policy, and decision-making (Bear and Woolley 2011; Conley and Stadmark 2012; Leisher et al. 2016). The low number of recognized female roles and contributions is one factor driving the exclusion of women in fisheries management decision-making processes. It is not only the focus on women and gender equality that is missing, but also a stronger focus on knowledge, vision, fairness, governance gender balance, and creative solutions to addressing marine environmental issues through collective action initiatives.

There is evidence that shows mixed-gender teams consistently outperform male and female single-gender teams in business fields, primarily because of the balance in experiences and opinions, which enhances group processes (Bear and Woolley 2011; Leisher et al. 2016). In addition, one study demonstrates that women are more willing than men to invest time in sustainable management processes, while men tend to just see a straightforward relationship between fishing and receiving income (Revollo-Fernández et al. 2016). Nevertheless, women's participation is more complex. In Cambodia, for example, women participate in fisheries management by having ties with men in powerful positions, supporting an elite to extract resources, therefore excluding other women without the right connections (Resurreccion 2008).

In this paper, we present the current situation of women in Mexican fisheries from case studies published in official reports and governmental programs. In addition, we share the field experiences acquired by Comunidad y Biodiversidad (COBI), a civil society organization (CSO), promoting sustainable fisheries. In the first section of the paper, we set out the legal and political landscapes that promote gender equality and women's empowerment at the national level, and the recent efforts to encourage gender parity in top decision-making positions. Then, we use the Gender Equality Capacity Assessment Tool of UN Women (2014) to analyze the available information from the agencies related to fisheries management and research. In the second section, we review how women's roles have been changing, with increased involvement in collective action in small coastal communities and contributions to fisheries' sustainability in the past decade, drawing insights from five case studies in Northwestern Mexico. Within each case study, we identify the three dimensions of empowerment (i.e., the ability to make strategic life choices) proposed by Kabeer (1999). Finally, we examine the broader context of gender relationships by describing the level of support from men to empower women.

\section{Women and fisheries in Mexico}

There are general policies in Mexico to promote women's empowerment and to achieve gender equality in the daily life of the country (Table 1 ). These policies were a cross-cutting strategy of the National Development Plan 2013-2018 (Gobierno de la Republica 2013), which reflected the implementation of gender mainstreaming strategies proposed by the United Nations (UN) at the 1995 Beijing Women's Conference. This approach aims to introduce a gender perspective, as a transversal strategy, across government institutions, policies, and programs. This top-down approach has been limited in scope as it does not necessarily address the root causes of gender-based inequalities and violence (Lamas 2012). Lamas (2012) suggests an alternative strategy which includes the mobilization of civil society organizations that provide a bottom-top perspective, in addition to the promotion of gender auditing and budgets with a gender perspective at the government level.

In the new, recently published National Development Plan 2019-2024, gender equality is again a cross-cutting strategy (Gobierno de la Republica 2019). While there is some evidence of progress in closing gender gaps, much still needs to be done to address gender inequalities. In December 2018, for the first time in Mexican history, the newly elected president presented a fully gender-balanced cabinet. Furthermore, the new senate and lower chamber are close to being balanced, with 63 women and 65 men, and 241 women and 259 men, respectively. From the available official data (i.e., since 2003), the compositions of both chambers (senate and lower chamber) have been, on average, $26 \%$ women and $74 \%$ men, and $31 \%$ women and 69\% men, respectively (InMujer 2019a, see Fig. 1). Finally, there is the National Institute of Women (InMujer), established in 2001, to promote non-discrimination, equal opportunities and treatment among genders, the application of women's rights, and the equal participation of women and men in the political, cultural, economic, and social life of Mexico. In March 2019, InMujer organized a workshop to present the National Development Plan 2019-2024, including discussions on important topics such as women's health, reproductive rights, education, participation in political and public processes, the national economy and economic empowerment, and discrimination and violence against women (InMujer 2019b). Nevertheless, setting aside the policies, there is an urgent need for actions to combat gender inequality, which in recent years has transformed into a surge of violence against women throughout the country. Between 2010 and 2016, there were seven femicides each day in Mexico (ONU Mujeres 2017). Gender inequalities may be especially prevalent in fishing communities where violence against women is well documented in other countries (Ratner et al. 2014; Kleiber et al. 2017). This is an issue that needs to be systematically assessed in the context of Mexican fisheries. 
Table 1 Mexican laws that promote gender equality (IUCN 2019; DOF 2018, 2019)

\begin{tabular}{|c|c|}
\hline Law & Aim \\
\hline Mexican Constitution & Women and men are equal in the eyes of the law \\
\hline $\begin{array}{l}\text { General Law for Equality between } \\
\text { Women and Men }\end{array}$ & $\begin{array}{l}\text { Guarantees equal opportunities in policies, } \\
\text { programs, projects, and instruments }\end{array}$ \\
\hline Planning Law & $\begin{array}{l}\text { Orders that any planning for the national } \\
\text { development and public federal administration } \\
\text { has to be based on equality of rights between } \\
\text { women and men }\end{array}$ \\
\hline $\begin{array}{l}\text { Federal Law on Budgeting and } \\
\text { Fiscal Responsibility }\end{array}$ & $\begin{array}{l}\text { Establishes that in the programming, budgeting, } \\
\text { approval, exercise, control, and evaluation of } \\
\text { federal income and public expenditures the } \\
\text { administration of resources is carried out with } \\
\text { accountability and gender equality, among } \\
\text { other criteria }\end{array}$ \\
\hline $\begin{array}{l}\text { General Law for Women to Access a } \\
\text { Life Free of Violence }\end{array}$ & $\begin{array}{l}\text { Guarantees a life with equal opportunities } \\
\text { and without violence for women }\end{array}$ \\
\hline
\end{tabular}

Mexico does not have a strong culture of women catching fish. Instead, women in small-scale fishing communities in general participate in fishing-related activities, often associated with household chores, making their contributions to fisheries invisible. In a few cases, women fish in specific coastal areas, mainly collecting invertebrates (e.g., clams) during low tide, something that also takes place in other cultures (Harper et al. 2013; Kleiber et al. 2015). For example, the Comcaác Indigenous group in the Gulf of California has an intertidal pen shell (Pinna rugosa and Atrina spp.) fishery exclusive to women and children (Basurto 2005); and women in San Felipe (Yucatan), they fish estuary crab (Libinia dubia), which are used by fishermen as bait to catch octopus (Octopus maya) (Perea-Blazquez and Flores-Palacios 2015) (Fig. 2). However, women also have important roles in landing, cleaning fish $(\text { deschuripar })^{2}$, registering and managing accounts and payments on the beach, and during the processing, sale, and preparation of fisheries products. They are also involved in fishing gear repair (e.g., traps). The fishing-related activities done by women on the beach are more frequently observed in small rural communities (i.e., communities with less than 15,000 people) than in larger towns, where women are more likely to work for large-scale processing plants or other productive sectors.

The government of Mexico's support for the participation and leadership of women in fisheries initiatives is, in practice, variable. We compare the most recent available official fisheries information from the National Commission of Aquaculture and Fisheries (CONAPESCA) and the National Fisheries and Aquaculture Research Institute (INAPESCA) with the six core gender capacities proposed by the United Nations Women (2014). This methodology evaluates the degree of understanding, knowledge, and skills of individuals

\footnotetext{
${ }^{2}$ A widely used term in Northwestern Mexico to describe the action of eviscerating and cleaning fish and other seafood on the beach.
}

and organizations on women's empowerment and gender equality and related policies, and helps create a route to improve these capacities. During our study, we did not identify a direct connection between the three capacities: gender analysis and strategic planning, gender and leadership, and innovation in gender transformative approaches. For the other capacities, the information is scattered.

For the core capacity gender-responsive programming, budgeting, and implementation we identified that in 2012, INAPESCA began implementing gender parity strategies during their hiring process (e.g., to ensure equal salaries and benefits) (INAPESCA 2012). In subsequent years, INAPESCA (2014) provided training to prevent violence against women, which involved emailing all personnel regarding gender equality. In 2016, CONAPESCA (2017a) announced government investments of approximately 45 million US dollars in projects aimed at supporting women's initiatives, including benefits for 11,000 women working in the fishing sector, without specifying the type of support or amount. Finally, InMujer, which in 2016 supported 79 projects led by women, had just one project from a fisherwomen's cooperative.

For the capacity knowledge management, communication and gender-responsive monitoring, and evaluation, we registered discrepancies on how many Mexican women are actually associated with the fisheries sector, directly and indirectly with sex-disaggregated data severely lacking for Mexican fisheries. The National Institute of Statistics and Geography (INEGI 2014a, 2014b; Lopez-Ercilla and Lopez-Sagastegui 2018) reported discrepancies in the 2014 economic census with two different numbers for the total number of people directly involved in marine and inland fishing and aquaculture activities, i.e., 181,122 and 188,566 people, of which $8 \%$ are reported to be women. Harper et al. (2017), based on the 2009 national census data, reported that 10,500 women in Mexico participate in the fishing sector, and finally CONAPESCA (2017a) reported that 22,000 women are directly associated 
Fig. 1 Percentage of 128 senators (a) and 500 lower chamber representatives (b) by sex
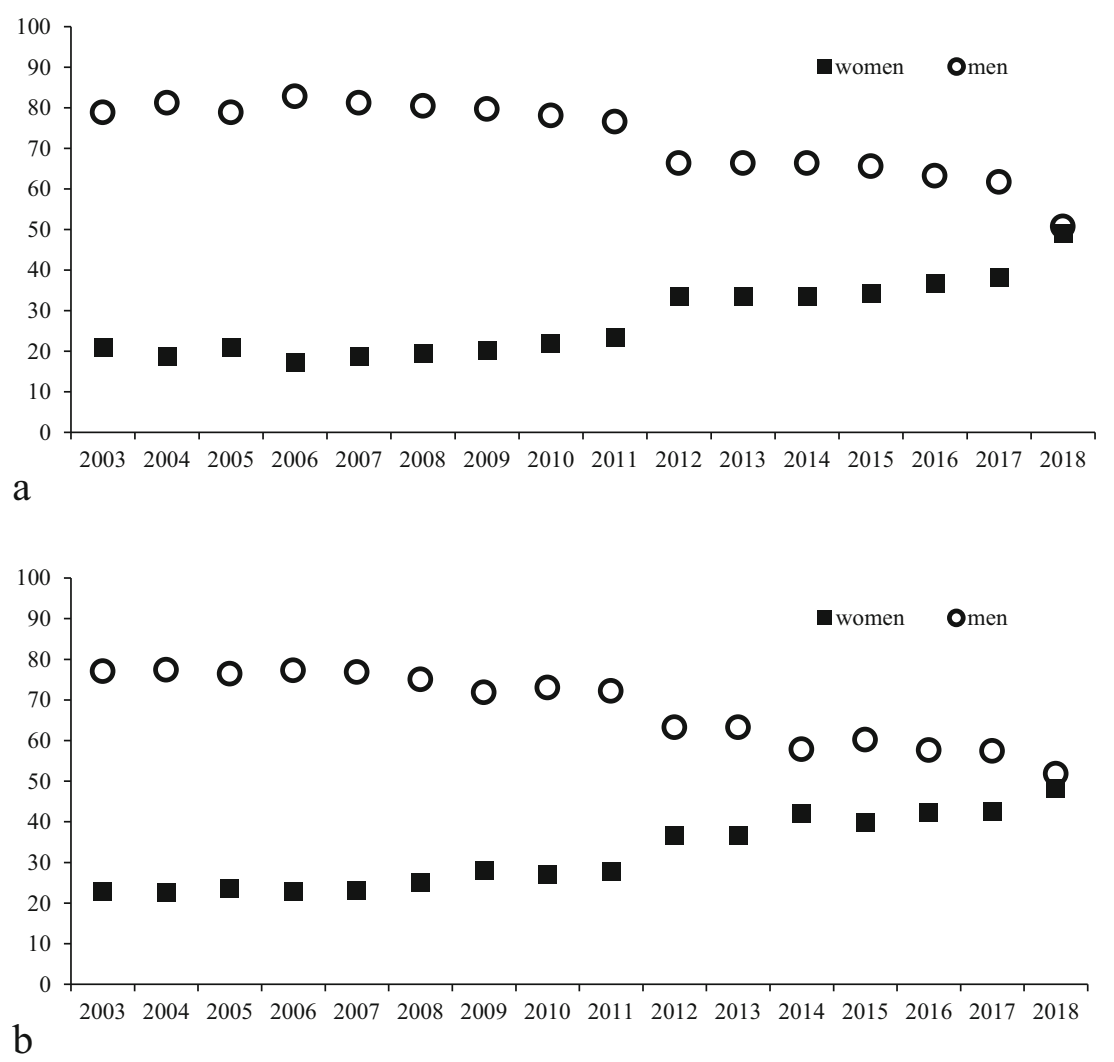

Fig. 2 Communities where women are implementing community-based marine conservation and fisheries best practices
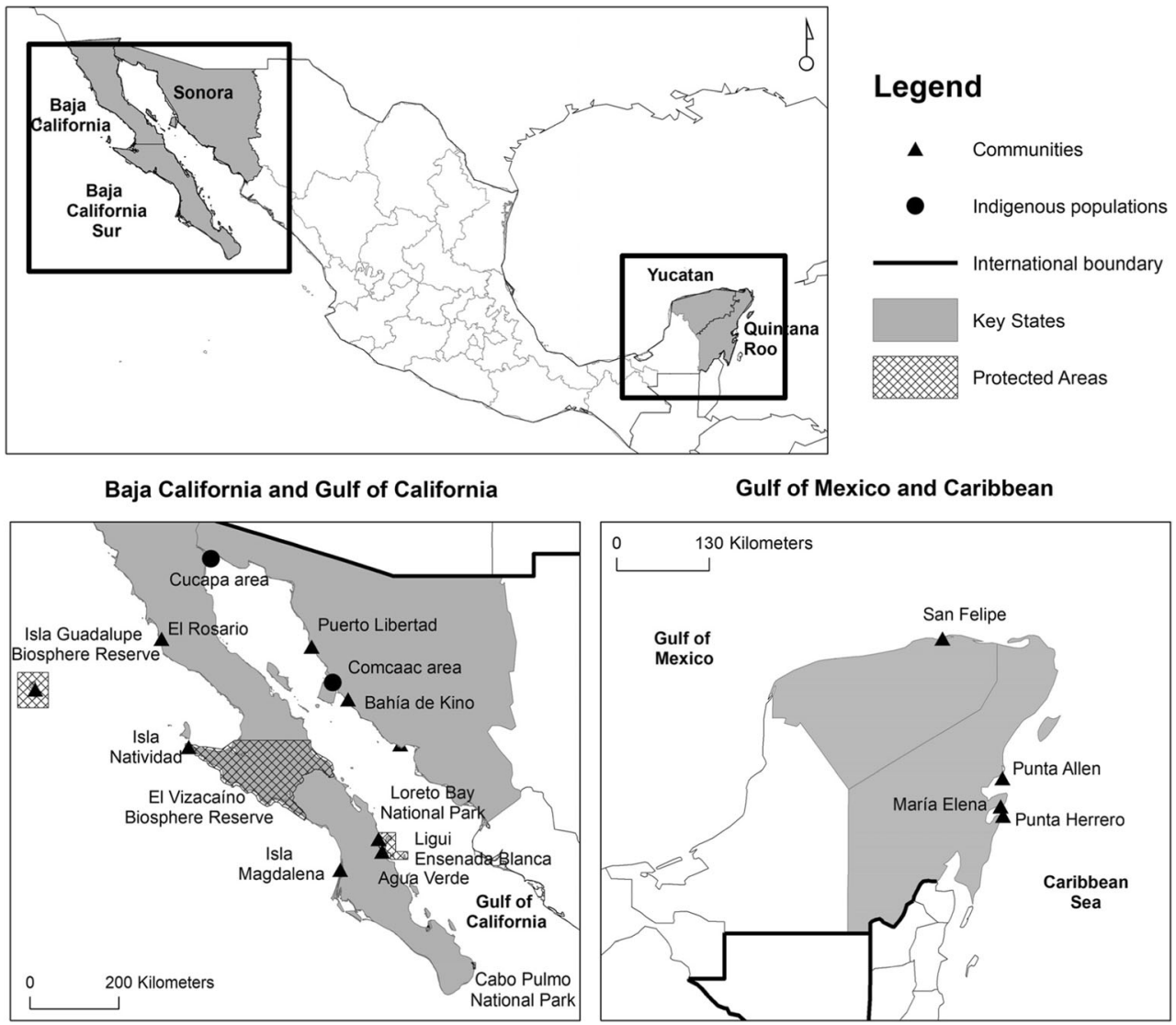
with the fishing sector, and that $48 \%$ of the people involved in the value-added processing chain for fisheries products are women (no number is reported).

In addition, the CONAPESCA (2017b) transparency office reported that, of the 4568 fishing (95\%) and aquaculture (5\%) permits and concessions that were approved between January 2016 and March 2017, 6\% of them were for women (244 fishing and 30 aquaculture). In the same report, CONAPESCA concluded that they do not have the data for the number of women working directly or indirectly in fisheries or processing plants. This is contrary to the information presented by CONAPESCA (2017a). Nevertheless, according to the Mexican Institute of Competitiveness (IMCO 2013), two million people depend directly and indirectly on fisheries in the country; therefore, we could estimate, according to the global tendency (World Bank 2012), that a million women could be associated with fisheries in Mexico. The only sexdisaggregated indicators reported since 2009 by CONAPESCA (2019) were for fisheries subsidies. The annual aquaculture and fisheries statistics report on the subsidy program for new outboard motors given to small-scale fishers (period 2009-2017, total $=29,451$ motors, annual mean $=$ 3722 ) indicated that on average, $10 \%$ of the beneficiaries of these subsidies were given to women (Fig. 3). Analyzing open access databases for CONAPESCA subsidies (fuel and boat modernization) from 2011-2016 (Pescando Datos 2019), we estimate that an annual average of $6 \%$ of the total number of subsidies $(31,238)$ in this period were assigned to women. Moreover, Pescando Datos (2019) reported that a man received eight times more money than a woman.

Finally, in the case of the capacity effective partnerships and advocacy on promoting gender equality, CONAPESCA (2018) organized the 8th Fisheries and Aquaculture Economic Forum including, for the first time, a panel on women's contributions to fisheries and aquaculture.

Mexico, as with many other countries, needs a systematic assessment of women's roles and contributions in fisheries, as at present they remain generally undocumented. In practice, no systematic efforts seem to be oriented to include women in decision-making or to understand masculinities (e.g., how men perceive and encourage gender equality in their daily lives). Harper et al. (2017) highlighted that information on the role of women in Mexican fisheries is very limited for direct and indirect fishing activities, management, governance, and decision-making, and there is no available information on catch volumes, gears, or other measures by gender in fisheries statistics. In addition, coherent mechanisms for improving gender equality in decision-making processes are immediately needed. The lack of information about gender reinforces the assumption that women are not involved in the fisheries sector, which further excludes them from decision-making forums or processes. In exceptional cases, women are included (e.g., widows that have inherited fishing permits/boats), and even then, they may receive criticism and harassment from their male peers for being in these spaces (Perea-Blazquez and Flores-Palacios 2015; Kleiber et al. 2017). More detailed sex-disaggregated data of participation by women and men through the fish value chain and in all fisheries-related activities, including management and decision-making, would allow for a gender analysis of public policies and subsidy programs associated with fisheries and aquaculture to identify inequalities (Kawarazuka et al. 2017).

\section{Methodology and case studies: women from traditional to modern roles}

This paper is based on interventions carried out by Comunidad y Biodiversidad (COBI), a CSO, in four coastal communities in Mexico between 2007 and 2017. The purpose of these interventions was to engage fishers in the design, establishment, and evaluation of no-take zones (EspinosaRomero et al. 2017; Torre and Fernández Rivera-Melo 2018). An additional program, included here as one of our case studies, focused on training men and women from small-scale fishing communities in leadership.

In the following section, we describe each case study by presenting the fishery context, the sustainable fisheries project being implemented, how the CSO approached the community, and the outcomes with respect to women's roles and participation in

Fig. 3 Percentage of annual new outboard motors given to smallscale fishers

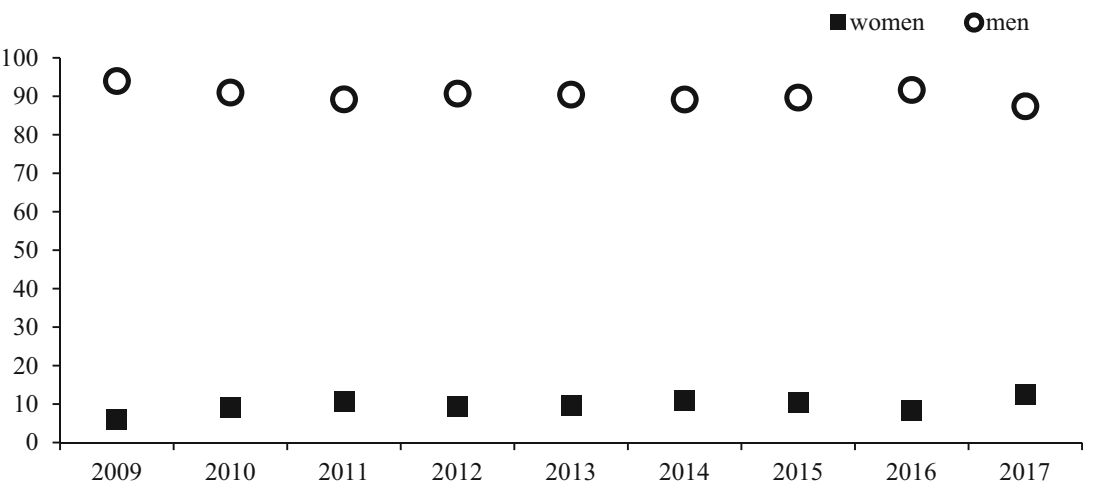


collective action. The cases are presented chronologically according to the date when women took the lead to participate in the projects. For each case, we also identify the three dimensions of empowerment described by Kabeer (1999) (i.e., resources, agency, and achievements) (Table 2).

\section{Ligüí (2007)}

Ligüí is a small coastal town (less than 200 people) within the Loreto Bay National Park (Gulf of California) (Fig. 2). The main fishing activities are clam harvesting (diving) and finfish (nets and hooks). The project carried out was associated with the sustainable fishing of aquarium species (invertebrates and fish) by the fishing cooperative Mujeres del Golfo established in 2000 by eight women. Currently, fifteen women are members of the cooperative and, in 2015, it was probably the only women's fishing cooperative out of a total of 254 cooperatives in the state of Baja California Sur (Nenadovic et al. 2018).

This initiative was a pilot project, running from 2005 to 2011, which aimed to assess the use of two fishery management tools (quotas and no-take zones) and propose a community-based strategy for the management of aquarium fisheries. COBI and the women's cooperative worked in close collaboration. During the first year of the project, a female and a male scientist led the project; then after the second year, the project lead was a woman, with a team of male technicians. In addition, the female president of the Mujeres del Golfo cooperative was a recognized and influential leader in the community. This initiative resulted in the publication of an official guidebook on aquarium fishery management by the national Ministry of Environment (SEMARNAT 2012; Germain et al. 2015). At the end of the project, the cooperative was able to assess, capture, process, and market local fisheries resources, and provide jobs for up to 35 people in the community, including the women's husbands. Unfortunately, 3 years later, the aquarium fishery ended due to a combination of factors including local and US buyers not paying the agreed prices. The new president of the cooperative also received threatening calls, and the cooperative, itself, suffered unfair competition from illegal fishing, increased transportation expenses (the product was sent to the USA by air from an airport that was a 5-h drive away), fishing permits not being renewed, and internal conflicts. More recently, the cooperative has restarted the process to obtain permits, and when asking the CSO for guidance in the process, they mentioned "it is time for us to take full responsibility."

As mentioned, the cooperative was established by an exceptional leader from the community, who has inspired many and made efforts to pass her knowledge on to the next generation of the cooperative. We also observed how a young woman (early 20s) stood out among the other cooperative members for her empathetic and collaborative leadership style. For example, in 2007, she participated in underwater monitoring (i.e., invertebrates and fish censuses) via SCUBA diving.

Table 2 Empowerment dimensions (resources, agency, and achievements) and level of support from men in each of the case studies

\begin{tabular}{|c|c|c|c|c|}
\hline Site & Resources & Agency & Achievements & Level of support from men \\
\hline Ligüí & $\begin{array}{l}\text { Access to fishing permits } \\
\text { Capacity in diving, monitoring, } \\
\text { fisheries management, and } \\
\text { aquarium species processing } \\
\text { Access to financial support } \\
\text { Relations with federal and state } \\
\text { government }\end{array}$ & $\begin{array}{l}\text { Apply for and obtain } \\
\text { governmental financial } \\
\text { support } \\
\text { Sell product to the best buyer } \\
\text { Invest in the cooperative } \\
\text { Hire husbands }\end{array}$ & $\begin{array}{l}\text { Provide jobs to women } \\
\text { and men from the } \\
\text { community } \\
\text { Participate in marine } \\
\text { reserves and fisheries } \\
\text { management } \\
\text { committees }\end{array}$ & $\begin{array}{l}\text { At the beginning, low, except for } \\
\text { the partners of the leaders } \\
\text { Nevertheless, with time, men in } \\
\text { the community began to } \\
\text { support the cooperative's } \\
\text { activities }\end{array}$ \\
\hline Isla Natividad & $\begin{array}{l}\text { Capacity in diving and } \\
\text { monitoring } \\
\text { Access to financial support } \\
\text { from CONANP } \\
\text { Women receive equal payment } \\
\text { as male monitoring divers }\end{array}$ & $\begin{array}{l}\text { Participate in research and } \\
\text { conferences to present climate } \\
\text { change information and their } \\
\text { experience as women monitors }\end{array}$ & $\begin{array}{l}\text { Recognition and support } \\
\text { from the cooperative } \\
\text { Investment in their own } \\
\text { diving equipment } \\
\text { including underwater } \\
\text { cameras }\end{array}$ & $\begin{array}{l}\text { Highly supportive, both husbands } \\
\text { and cooperative members } \\
\text { The fishing cooperative expresses } \\
\text { pride for the women's } \\
\text { achievements }\end{array}$ \\
\hline Isla Magdalena & $\begin{array}{l}\text { Capacity in eco-technology to } \\
\text { design and build houses } \\
\text { (eco-bricks) }\end{array}$ & $\begin{array}{c}\text { Besides the decision to participate, } \\
\text { no other agency was observed }\end{array}$ & $\begin{array}{l}\text { No achievements were } \\
\text { observed }\end{array}$ & $\begin{array}{l}\text { Indifferent } \\
\text { Women never were integrated } \\
\text { into the cooperative's } \\
\text { decisions }\end{array}$ \\
\hline Isla Guadalupe & $\begin{array}{l}\text { Capacity in diving and } \\
\text { monitoring } \\
\text { Receive equal payment as male } \\
\text { monitoring divers }\end{array}$ & $\begin{array}{l}\text { Participate in monitoring } \\
\text { climate change } \\
\text { Apply and obtain governmental } \\
\text { financial support }\end{array}$ & $\begin{array}{l}\text { They are involved in other } \\
\text { government projects }\end{array}$ & $\begin{array}{l}\text { Men from the cooperative } \\
\text { support women's monitoring } \\
\text { activities }\end{array}$ \\
\hline $\begin{array}{r}\text { Leadership } \\
\text { program }\end{array}$ & $\begin{array}{l}\text { Capacity in leadership } \\
\text { Knowledge to start a fishing } \\
\text { cooperative } \\
\text { Access to aquaculture permits }\end{array}$ & $\begin{array}{l}\text { Start a cooperative } \\
\text { Apply and obtain government } \\
\text { financial support }\end{array}$ & $\begin{array}{l}\text { Participate in marine } \\
\text { reserves and fisheries. } \\
\text { management } \\
\text { committees }\end{array}$ & $\begin{array}{l}\text { Men support women's } \\
\text { initiatives }\end{array}$ \\
\hline
\end{tabular}


Previously, diving had not been an activity that women in the community did, so by taking on this task, she demonstrated that women could also participate in these activities. She has also been strongly supported by her husband, he is her diving partner during monitoring activities, and during her travels, he takes care of their child and domestic duties. The Ligüí cooperative has been a significant motivating factor for other women's groups in Northwestern Mexico, including Indigenous Cucapa fisherwomen and women from five other fishing communities along the Baja California peninsula (Isla Natividad, Isla Guadalupe, Cabo Pulmo, Ensenada Blanca, and Agua Verde). The story of this cooperative has been the inspiration for newspaper stories and a famous national TV soap opera series What we women keep silent (Lo que callamos las mujeres). The episode of this series was called Las Golfas: a derogatory term used in Mexico to refer to a prostitute, and at the same time the nickname for this group due to the cooperative's name Mujeres del Golfo. The episode tells the story of the cooperative and the women who struggle to be accepted as entrepreneurs ${ }^{3}$.

\section{Isla Natividad (2011)}

Isla Natividad is a small island $\left(8.6 \mathrm{~km}^{2}\right)$, inside El Vizcaino Biosphere Reserve, located $8 \mathrm{~km}$ from the Baja California coast in the Pacific Ocean, with approximately 400 inhabitants, of which 68 men and 4 women are members of the fishing cooperative Buzos y Pescadores de la Baja California established in 1942. This cooperative and eight others in the region have been recognized worldwide for their successful actions toward sustainable resource management that includes (1) cooperation for the common good, (2) co-management, (3) territorial use fishing rights (TURFs) with 20-year fishing concessions, and (4) a long-term vision for a sustainable economy and environment (Sanchez-Bajo and Roelants 2011; McCay et al. 2014). The main species targeted by the cooperative members are high-value species such as abalone and lobster, and some other invertebrates (snail and sea cucumber) and finfish. The lobster fishery was certified in 2004 by the Marine Stewardship Council (MSC) and was the first Latin American small-scale fishery to receive this certification.

COBI started its collaboration with this cooperative in 2005 , establishing two voluntary no-take marine reserves in 2006 which were formalized in 2018 by CONAPESCA as fish refuges. The role of COBI on the island has been, along with other researchers, to foster collaboration with the cooperative and work together to promote citizen science, sustainable management, and marine conservation.

\footnotetext{
${ }^{3}$ This TV episode is available on YouTube (https://www.youtube.com/watch? $\mathrm{v}=$ N0iCoVTaexc).
}

In 2011, a group of seven women (fishers' wives) from the island approached COBI requesting dive training, so that they could improve their knowledge of marine ecosystems and resources. They asked why COBI only trained and worked with fishermen and did not include women. Two female scientists led COBI's team, which consisted of staff and students of both sexes, conducting the same activities (i.e., diving, monitoring, teaching, interviewing). The women's initiative was fully supported by the cooperative and their partners. Today, these women collaborate on international research projects (e.g., with Stanford University), monitoring the environment (underwater data collection, data processing, and sharing with national and international researchers), climate change (e.g., installing and maintaining underwater oceanographic sensors that measure $\mathrm{pH}$, salinity, temperature, and dissolved oxygen), and no-take zones associated with the cooperatives. In addition, this group of women has presented the results at national and international conferences (e.g., Caribbean and Gulf Fisheries Institute 2016) obtaining financial support to attend from the cooperative and from COBI, and through fundraising efforts within the community. These women have inspired other women from the island.

\section{Isla Magdalena (2012)}

This island $\left(314 \mathrm{~km}^{2}\right)$ is located in the lagoon complex of Magdalena Bay, Baja California Sur, with a population of 200 people, which can increase to 500 depending on the fishing season. The fishing cooperative of the island, Bahia Magdalena, was established in 1985 and has permits for finfish and lobster and a benthic resource (abalone) fishing concession (TURF). The island also has tourism activities such as sport fishing and gray whale watching. From 2008 to 2015, COBI collaborated with the cooperative on the implementation and assessment of a voluntary marine reserve.

In 2012, a group of seven local women participated in the design and construction of a multipurpose community space, using eco-friendly materials. This was built to support the island's community where hurricanes have, in recent years, destroyed houses and its assembly hall. Few men participated in this project, firstly, because they did not have time due to their fishing activities and, secondly, due to a lack of interest. Therefore, the women who participated not only contributed ideas to the design of the buildings, but they were also involved in the manufacture and mobilization of materials for construction (Murillo and Lejbowicz 2014). Overall, the women never received strong support from the men on the island or from the cooperative because the initiative was perceived as a pastime for the women. Two women from COBI led the project in collaboration with a staff team of men. In 2014, the assembly hall was finished; but in January 2015, the fishing cooperative decided to open the reserve due to economic crisis and stopped working with COBI. The subsequent 
phases for the construction of a sustainable town were halted, and the team of women did not continue collaborating on the project, returning to their daily housework.

\section{Isla Guadalupe (2013)}

This remote oceanic island $\left(253 \mathrm{~km}^{2}\right)$ is located $241 \mathrm{~km}$ from the mainland in the Mexican Pacific Ocean. The island is a hot spot for great white shark (Carcharodon carcharias) research and tourism. Around 100 fishers and their families live on the island, and by 1952 , they had established a fishing cooperative named Abuloneros y Langosteros. In 2005, the island and its adjacent waters were included in a biosphere reserve. During the design and assessment of voluntary no-take zones to protect abalone around the island, a group of eight women were trained in diving and monitoring techniques. Women were also trained to install oceanographic sensors and today continue working closely with the National Commission on Natural Protected Areas (CONANP) to monitor climate change.

In this case, as for Isla Natividad, two women researchers led the project, setting an example of female leadership. Additionally, the director and rangers of the Biosphere Reserve were women who provided support to female and male community and cooperative members. Today, these women are in charge of underwater climate change monitoring using oceanographic sensors, with the recorded information (e.g., temperature and oxygen levels) being used by the fishing cooperative to decide when to fish and to enhance product labeling.

\section{The leadership program (2013)}

This program, designed and implemented by COBI as a Community Leadership Program, was aimed at strengthening human dimensions as well as developing skills and knowledge to allow the sustainable management of coastal resources. The participants also received a coaching process. The applied curriculum included leadership and cooperation courses for the common good, effective communication, negotiation and conflict resolution, fisheries management and organization, basic finances, and tools for the sustainable management of marine resources fisheries. The program was replicated, with adaptations, by two other CSOs (Sociedad de Historia Natural Niparajá and Environmental Defense FundMexico) in the region. By 2017, a total of 13 women and 25 men from 18 coastal communities in Northwestern Mexico had graduated from this program. Each participant developed projects focusing on conservation and sustainable fisheries, including teaching best practices, promoting sustainable fisheries, fostering strong fishers' organizations, ecosystem restoration, recycling, and alternative livelihoods. One participant shared his experience with this transformative program: "I learned that being a leader does not mean sitting on a throne and giving orders." In 2017, a new generation of leaders started the program with Gender Equality at Sea as the theme.

Three women from the small town of Bahía de Kino, Gulf of California, who participated in this program went on to start their own cooperative that they described as a "restoration cooperative" with the main goal being the restoration of the clam population in the local estuary. In 2017, they obtained a 7-hectare aquaculture concession, clam seeds, and financial support from the government. In addition, they worked with their family members to reduce illegal fishing and promote beach cleanup activities and plastic recycling campaigns. Another woman from Puerto Libertad (2500 people), with her partner, is implementing sustainable fishing best practices in the finfish fishery and constructing a small processing plant to add value to the catch.

The case studies presented above demonstrate that COBI's efforts to promote sustainable fisheries have contributed also to the improvement of opportunities for women and men and have changed gender relations within coastal communities. The training courses and qualifications provided allowed women to improve their capacities and skills, as well as establish cooperatives and develop their own projects. These changes were also enabled by the strong presence of women within COBI's staff team, especially in management positions, and taking part in traditionally male activities, such as diving and monitoring.

In the following section, we will examine the impact of COBI's actions aimed at increasing the roles and participation of women in conservation and sustainable fisheries through the lens of empowerment developed by Kabeer (1999), and how this supported collective action and gender equality.

\section{Discussion: New knowledge, new roles, new relations, and empowerment}

Through the various case studies highlighted here, we observed that decisions made by individual women became examples that others followed. The decision made by one woman to participate in an underwater monitoring program was an inspiration to women from other communities. For example, this inspired women from six Mexican coastal communities to diversify their roles, and they are now monitoring marine biodiversity as part of collective actions by the community to promote sustainability. Participation by women from the CSOs in collective action and in leadership programs also provided an example to others of what could be done.

The social transformation in terms of gender relations, initiated by COBI's actions, contributed toward women's empowerment. In the following, we will discuss the different interventions, taking Kabeer's (1999) theory, especially the concept of empowerment, into consideration. Empowerment is defined by Kabeer (1999) as the capacity to make strategic life choices, especially in a context where this ability was 
previously denied to them. In this case, the capability to make these choices should be thought of in terms of three interrelated dimensions: resources (pre-conditions), agency (process), and achievements (well-being, outcomes).

\section{Resources}

The results were possible due to the available resources and training brought about by this external intervention. As documented in the Guadalupe and Natividad islands case studies, women received SCUBA training and equipment (e.g., oceanographic sensors) to monitor invertebrate and fish abundances and climate change variables (e.g., temperature, oxygen) in the notake zones. Similar capacities were instilled in the Mujeres del Golfo cooperative, where women were trained in activities associated with fishing for aquarium species. In the case of Isla Magdalena, women and men were trained in eco-technology to design and build houses. Finally, women from Bahía de Kino received leadership training skills. Aside from the women from Isla Natividad, who asked specifically to be trained and integrated into the project, the impetus to include women in most of these projects came from COBI. Women who participated in underwater monitoring activities received equal payment as men. Women in all the communities also got access to fishing resources, aquaculture permits, or financial support (governmental, cooperative, private donors).

\section{Agency}

As part of these various initiatives, women developed leadership, decision-making, and negotiation skills. Examples of this included starting their own cooperatives, applying for fishing/aquaculture permits and governmental financial support, investing in their cooperatives, diving and processing equipment, selling their products to the best buyer, hiring people from their community, and incorporating their partners in cooperative activities. We also observed women being resourceful and self-sufficient to cover expenses. For example, women cooked food, cakes, cookies, and other sweets to fund their initiatives, as payment for paperwork to start a cooperative or to cover expenses to participate in meetings.

Changes in gender relations were also observed. For example, men supported women's involvement in the cooperatives and are partners in the projects to different degrees. The support and interest given by the cooperatives and partners to the women undertaking monitoring activities varied from low support on Isla Magdalena to strong support on Guadalupe and Natividad islands. The same is happening in other small-scale fishing communities in Mexico (El Rosario, Punta Allen, Punta Herrero, and María Elena) (Fig. 2). On one occasion where women were participating and presenting in a scientific conference, the cooperative's (male) directors were present to manifest their support and the cooperative's pride in the women's achievements. The gradual support of men toward women's fishing-related activities has been documented for the women's fishing cooperative that extracts estuary crabs for the octopus fishery in Yucatan (PereaBlazquez and Flores-Palacios 2015). The authors describe how men at the beginning were not supportive but over time, this changed. A similar shift was observed in the case of the Mujeres del Golfo.

\section{Achievements}

Knowledge acquired by women through their new roles also gave them the opportunity to participate in collective actions and decision-making on the same level as fishermen. The various case studies suggest that empowerment of women in remote small coastal communities could be achieved by acquiring new skills (e.g., diving, monitoring), knowledge of the ecosystems where they live, ecology and fisheries sciences, and financial support. The result was that women were then able to influence decisions about their future, form and manage a cooperative, apply to obtain fishing and aquaculture permits and subsidies, or participate in scientific research and conferences to present their results.

We identified three drivers that contribute to women's empowerment in small-scale fisheries. First, the presence of strong female role models: women leading marine conservation projects in the field - doing stereotypically "male" activities such as diving - inspired women in the communities to acquire confidence and skills to lead research projects. Latu et al. $(2013,2018)$ discuss how this type of empowering behavior (e.g., mimicry) is the result of exposure to female role models compared with only male role models or no role models. In addition, women from communities such as that in Isla Guadalupe were empowered by women in the federal administration (e.g., CONANP) as was previously reported by Frangoudes et al. (2013) for the mariscadoras of Spain. The second driver was the presence of men in the communities who were highly supportive of the professional development of their partners, expressed through pride in working together in the field as equals, and taking care of the household chores and children. For example, a father teaching his daughter to fish (Perea-Blazquez and Flores-Palacios 2015) or inspiring her to dive as he did in the past. Finally, the support of the CSO through this process was also important in supporting women's empowerment by promoting equal opportunities and facilitating the incorporation of women into each project.

We saw through these examples that women are leaders and visionaries with respect to sustainably managing fisheries (Revollo-Fernández et al. 2016). Women sought to participate in all the different management stages, from evaluation to decision-making, with the necessary social sensitivity (Woolley et al. 2010), empathy, ability to collaborate, and willingness to learn and promote change. Leadership has been 
identified as the main factor to achieve sustainable fisheries in communities (Gutiérrez et al. 2011). Throughout the process of women's empowerment, we have observed transformations within communities, with the government, researchers, and CSOs. This is best exemplified by the leader of the fishing cooperative Mujeres del Golfo during a large (over 100 people) fisheries workshop (2014). Here, the leader said: "Before the training, I was afraid and mortified to talk with researchers, I would just listen to them. Now I can sit and discuss with them the results of their studies, because I know what they are talking about. I am not afraid anymore."

Comparing these case studies, we identified new roles that women have taken on through their participation in collective action around conservation and sustainable fisheries. First and foremost, women are collaborating in the restoration of marine ecosystems and fisheries by strong involvement in the monitoring of marine reserves and implementation of best practices for fisheries management. Second, women are also participating in monitoring environmental changes. In the last decade, 30 women from three regions in Mexico (kelp forests on the Pacific side of the Baja California peninsula, rocky-reefs in the Gulf of California, and coral reefs in the Caribbean Sea) have been trained in SCUBA diving and underwater monitoring techniques (Fulton et al. 2019). Third, these women are teaming up with their peers to form mixed-gender monitoring groups. Fourth, the collection of scientific data generates responsibility, pride, and profound understanding of the ecosystem which have positive social (e.g., recognition by the families and communities) and ecological (e.g., protection of natural resources) benefits for the community and marine ecosystem (Fulton et al. 2019). Fifth, where these monitoring teams have achieved gender parity, capacity for collective action improved with increased support and participation and by combining different perspectives and skills.

\section{Conclusion}

Gender equality is increasingly understood as fundamental to advancing sustainability in small-scale fisheries and must be incorporated into collective actions. In the case of Mexico, many changes are still needed to achieve gender equality in the fisheries sector. Existing inequalities need to be identified and women's contributions to fisheries need to be recognized. Here, we highlight that the emergence of new roles for women is mainly the product of community organizations working with other stakeholders. The overall positive outcomes from the cases presented here hinge on complementary actions across groups that transcend the mainstreaming governmental strategies. CSOs play an important role in a cross-cutting implementation of a gender perspective, with the proper training and sensitivity to carry out the intervention.
Through analyzing these case studies from Mexico, we found that increased participation of women in fisheries decision-making processes was closely linked to acquiring new skills and leadership capacities and being inspired by existing female role models. To further encourage their empowerment in this space, women must also be able to participate in meetings, be free to voice their opinions, and vote on the same terms as men. In addition, attention must be drawn to incorrect practices of gender equality and women's issues as a political leveraging tool by stakeholders, politicians, and governmental agencies.

Acknowledgments This research focusing on marine conservation and sustainable fisheries has been carried out during the last decades thanks to the support of Alianza WWF-Fundación Carlos Slim, David and Lucile Packard Foundation, Fondo Mexicano para la Conservación de la Naturaleza, International Community Foundation, Marisla Foundation, Stanford University, Sandler Supporting Foundation, Summit Foundation, The Nature Conservancy, and Walton Family Foundation. We thank A.P. Suarez and L.F. Rodriguez for the CONAPESCA transparency office report data and P. Zapata for the INAPESCA information. We are deeply grateful of the trust and knowledge shared by the women in the coastal communities and fishers, and the inspiration and leadership of A. Saenz-Arroyo and F. Micheli. We especially thank K. Fragoudes, S. Gerrard, S. Harper, D. Kleiber, J. Garcia Hernandez, S. Fulton, and an anonymous reviewer for the revisions. We thank R. Saini for her recommendation for the financial support.

Author contributions All the authors contributed to the conceptualization, data, and writing of the manuscript.

Funding information This compilation was supported by the Leona M. and Harry B. Helmsley Charitable Fund for the project "Gender equality in the sea, the missing key piece for successful marine conservation."

\section{Compliance with ethical standards}

Conflict of interest The authors declare that they have no conflict of interest.

Open Access This article is distributed under the terms of the Creative Commons Attribution 4.0 International License (http:// creativecommons.org/licenses/by/4.0/), which permits unrestricted use, distribution, and reproduction in any medium, provided you give appropriate credit to the original author(s) and the source, provide a link to the Creative Commons license, and indicate if changes were made.

\section{References}

Basurto, X. 2005. How locally designed access and use controls can prevent the tragedy of the commons in a Mexican small-scale fishing community. Society and Natural Resources 18: 643-659.

Bear, J.B., and A.W. Woolley. 2011. The role of gender in team collaboration and performance. Interdisciplinary Science Reviews 36: 146153.

Branch, T.A., and D. Kleiber. 2017. Should we call them fishers or fishermen? Fish and Fisheries 18: 114-127. 
CONAPESCA. 2017a. SAGARPA-CONAPESCA ha invertido 880 millones de pesos en proyectos pesqueros y acuícolas en beneficio de 11 mil mujeres. Sala de Prensa. 2017. https://www.gob.mx/ conapesca/prensa/sagarpa-conapesca-ha-invertido-880-millonesde-pesos-en-proyectos-pesqueros-y-acuicolas-en-beneficio-de-11mil-mujeres. Accessed 25 Abr 2019.

CONAPESCA. 2017b. Tercera reunion del ejericio fiscal 2017. http://conapesca.gob.mx/work/sites/cona/leytransparencia/ 2017/TERCERA_SESION_ORDINARIA_MARZO_17.pdf. Accessed 25 Abr 2019.

CONAPESCA. 2018. Contribucion de la Mujer a la Pesca y la Acuacultura. https://foroeconomico.conapesca.gob.mx. Accessed 25 Abr 2019.

CONAPESCA. 2019. Anuario Estadistico de Acuacultura y Pesca. https://www.gob.mx/conapesca/documentos/anuario-estadistico-deacuacultura-y-pesca. Accessed 25 Abr 2019.

Conley, D., and J. Stadmark. 2012. A call to commission more women writers. Nature 488: 590-590.

DOF. 2018. Ley general de accesso de las mujeres a una vida libre de violencia. Diario Oficial de La Federacion.

DOF. 2019. Constitucion Politica de los Estados Unidos Mexicanos. Diario Oficial de La Federacion.

Espinosa-Romero, M.J., J. Torre, J.A. Zepeda, F.J. Vergara-Solana, and S. Fulton. 2017. Civil society contributions to the implementation of the small-scale fisheries guidelines in Mexico. In Unpacking the voluntary guidelines for securing sustainable small-scale fisheries - from rhetoric to action, ed. S. Jentoft, R. Chuenpagdee, M.J. Barragán-Paladines, and N. Franz, vol. 14, 423-449, MARE Publications Series. Cham: Springer.

FAO. 2014. The state of world fisheries and aquaculture 2014. Opportunities and challenges. Rome: Food and Agriculture Organization of the United Nations.

FAO. 2015. Voluntary guidelines for securing sustainable small-scale fisheries in the context of food security and poverty eradication. Rome: Food and Agriculture Organization of the United Nations.

Frangoudes, K., and S. Gerrard. 2018. (En)Gendering change in smallscale fisheries and fishing communities in a globalized world. Maritime Studies 17: 117-124.

Frangoudes, K., B. Marugán-Pintos, and J.J. Pascual-Fernandez. 2013. Gender in Galician shell-fisheries: transforming for governability. In Governability of fisheries and aquaculture: theory and applications, ed. M. Bavinck, R. Chuenpagdee, S. Jentoft, and J. Kooiman, vol. 7, 241-261 MARE Publications Series. Cham: Springer.

Fulton, S., A. Hernández-Velasco, A. Suarez-Castillo, F. Fernández Rivera-Melo, M. Rojo, A. Sáenz-Arroyo, A.H. Weaver, R. Cudney-Bueno, F. Micheli, and J. Torre. 2019. From fishing fish to fishing data: the role of artisanal fishers in conservation and resource management in Mexico. In Viability and sustainability of small-scale fisheries in Latin America and The Caribbean, ed. S. Salas, M.J. Barragán-Paladines, and R. Chuenpagdee, vol. 19, 151175, MARE Publications Series. Cham: Springer

Germain, N., H.J. Hartmann, F.J. Fernández-Rivera Melo, and H. ReyesBonilla. 2015. Ornamental reef fish fisheries: new indicators of sustainability and human development at a coastal community level. Ocean and Coastal Management 104: 136-149. https://doi.org/10. 1016/j.ocecoaman.2014.12.007.

Gobierno de la Republica. 2013. Plan Nacional de Desarrollo 2013-2018. http://www.snieg.mx/contenidos/espanol/normatividad/ MarcoJuridico/PND 2013-2018.pdf. Accessed 25 Abr 2019.

Gobierno de la Republica. 2019. Plan Nacional de Desarrollo 2019-2024. http:/gaceta.diputados.gob.mx/PDF/64/2019/abr/20190430-XVIII1.pdf. Accessed 1 July 2019.

Gutiérrez, N.L., R. Hilborn, and O. Defeo. 2011. Leadership, social capital and incentives promote successful fisheries. Nature 470: 386389
Harper, S., D. Zeller, M. Hauzer, D. Pauly, and U.R. Sumaila. 2013. Women and fisheries: contribution to food security and local economies. Marine Policy 39: 56-63.

Harper, S., C. Grubb, M. Stiles, and U.R. Sumaila. 2017. Contributions by women to fisheries economies: insights from five maritime countries. Coastal Management 45: 91-106.

IMCO. 2013. La Pesca Ilegal e Irregular En Mexico: Una Barrera a La Competitividad. https://imco.org.mx/wp-content/uploads/2013/5/ pesca_ilegal.pdf. Accessed 25 Abr 2019.

INAPESCA. 2012. Dan reconocimiento a INAPESCA por acciones de equidad de genero. Sala de Prensa. 2012. https://www.gob.mx/ inapesca/prensa/dan-reconocimiento-a-inapesca-por-acciones-deequidad-de-genero. Accessed 25 Abr 2019.

INAPESCA. 2014. Eliminacion de la violencia de la mujer en el INAPESCA. http://inapesca.gob.mx/portal/documentos/ recursoshumanos/Reporte-Eliminacion-de-la-Violencia-de-laMujer-Marzo-25.pdf. Accessed 25 Abr 2019.

INEGI. 2014a. Las mujeres y los hombres en las actividades económicas. http://www.beta.inegi.org.mx/contenidos/proyectos/ce/2014/doc/ minimonografias/m_myhae_ce2014.pdf. Accessed 25 Abr 2019.

INEGI. 2014b. Pesca y Acuicultura. http://www.beta.inegi.org.mx/ contenidos/proyectos/ce/2014/doc/minimonografias/mpesca ce2014.pdf. Accessed 25 Abr 2019.

InMujer. 2019a. Estadísticas de mujeres: indicadores de inclusión social, igualdad y empoderamiento. Gobierno de La Republica. InMujer. 2019. https://datos.gob.mx/busca/dataset/estadisticas-de-mujeresindicadores-de-inclusion-social-igualdad-y-empoderamiento. Accessed 25 Abr 2019.

InMujer. 2019b. Foro Especial de Consulta Ciudadana Para El Plan Nacional de Desarrollo (PND) Sobre Mujeres. Sala de Prensa. https://www.gob.mx/inmujeres/prensa/foro-mujeres-pnd-20192024?idiom=es. Accessed 21 July 2019.

IUCN. 2019. Programa de Adaptación Al Cambio Climático de La Región de Las Grandes Islas, Sonora. Plan de Accion de Genero. http://genderandenvironment.org/resource/programa-deadaptacion-al-cambio-climatico-de-la-region-de-las-grandes-islassonora-plan-de-accion-de-genero/. Accessed 25 Abr 2019.

Kabeer, N. 1999. Resources, agency, achievements: reflections on the measuremente of wome's empowerment. Development and Change 30: 435-464.

Kalikoski, D.C., and N. Franz. 2013. Strengthening organizations and collective action in small-scale fisheries. Rome: FAO Workshop. Food and Agriculture Organization of the United Nations.

Kawarazuka, N., C. Locke, C. McDougall, P. Kantor, and M. Morgan. 2017. Bringing analysis of gender and social-ecological resilience together in small-scale disheries research: challenges and opportunities. Ambio 46: 201-213. https://doi.org/10.1007/s13280-0160814-5.

Kleiber, D., L.M. Harris, and A.C.J. Vincent. 2015. Gender and smallscale fisheries: a case for counting women and beyond. Fish and Fisheries 16: 547-562.

Kleiber, D., K. Frangoudes, H. T. Snyder, A. Choudhury, S. M. Cole, K. Soejima, C. Pita, A. Santos, C. McDougall, H. Petrics, and M. Porter. 2017. Promoting gender equity and equality through the small-scale fisheries guidelines: experiences from multiple case studies. In The small- scale fisheries guidelines global implementation, ed. N. Jentoft, S. Chuenpagdee, R. Barragán-Paladines, and M.J. Franz, 14, 737-759, MARE Publications Series Cham: Springer.

Lamas, M. 2012. El enfoque de género en las políticas públicas. Revista de Derechos Humanos Dfensor 85-92.

Latu, I.M., M. Schmid Mast, J. Lammers, and D. Bombari. 2013. Successful female leaders empower women's behavior in leadership tasks. Journal of Experimental Social Psychology 49: 444-448.

Latu, I.M., M. Schmid Mast, D. Bombari, J. Lammers, and C.L. Hoyt. 2018. Empowering mimicry: female leader role models empower 
women in leadership tasks through body posture mimicry. Sex Roles 80: 11-24.

Leisher, C., G. Temsah, F. Booker, M. Day, L. Samberg, D. Prosnitz, B. Agarwal, E. Matthews, D. Roe, D. Russell, T. Sunderland, and D. Wilkie. 2016. Does the gender composition of forest and fishery management groups affect resource governance and conservation outcomes? A systematic map. Environmental Evidence 5: 1-10.

Lopez-Ercilla, I., and R. Lopez-Sagastegui. 2018. Las mujeres y el sector pesquero en Mexico. Datamares. https://doi.org/10.13022/ M30K9N. Accessed 25 Abr 2019.

McCay, B.J., F. Micheli, G. Ponce-Diaz, G. Murray, G. Shester, S. Ramirez-Sanchez, and W. Weismang. 2014. Cooperatives, concessions, and co-management on the Pacific coast of Mexico. Marine Policy 44: 45-59.

Murillo, R., and A. Lejbowicz. 2014. Guia para la concepcion y edificacion del pueblo costero sustentable en Isla Magdalena, Baja California Sur, Mexico. https://www.google.com/search?client= safari\&rls=en\&q=.+http://cobi.org.mx/wp-content/uploads/2014/ 12/2014-guia-pueblo-costero-sustentable-COBI.pdf\&ie=UTF8\&oe=UTF-8. Accessed 25 Abr 2019.

Nenadovic, M., X. Basurto, M. J. Espinosa, S. Huff, J. López, C. Méndez Medina, D. Valdez, S. Rodríguez Van Dyck, and A. H. Weaver. 2018. Diagnostico Nacional de Organizaciones Pesqueras. Comunidad y Biodiversidad, Confederacion Mexicana de Cooperativas Pesqueras y Acuicolas. Duke University and Sociedad de Historia Natural Niparaja. http://s3.amazonaws.com/ inforural.com.mx/wp-content/uploads/2018/10/11081712/ Diagnostico-Nacional-de-Organizaciones-Pesqueras-en-MéxicoDNOP.pdf. Accessed 1 July 2019.

ONU Mujeres. 2017. La Violencia Feminicida En México, Aproximaciones y Tendencias 1985-2016. https://www.gob.mx/ cms/uploads/attachment/file/84740/La_Vilencia_Feminicida_en M_xico_aproximaciones_y_tendencias_1985_-2014.pdf. Accessed 25 Abr 2019.

Perea-Blazquez, A., and F. Flores-Palacios. 2015. Participación de las mujeres en la pesca: nuevos roles de género, ingresos económicos y doble jornada. Sociedad y Ambiente 1: 121-141.

Pescando Datos. 2019. ¿Como se distribuyen los subsidios a la pesca en Mexico?. http://pescandodatos.org. Accessed 25 Abr 2019.
Ratner, B.D., B. Asgard, and E.H. Allison. 2014. Fishing for justice: human rights, development, and fisheries sector reform. Global Environmental Change 27: 120-130. https://doi.org/10.1016/j. gloenvcha.2014.05.006.

Resurreccion, B.P. 2008. Gender, legitimacy and patronage-driven participation: fisheriesmanagement in the Tonle Sap Great Lake, Cambodia. In Gender and Natural Resource Management, ed. B.P. Resurreccion and R. Elmhirst, 151-174. Earthscan.

Revollo-Fernández, D., A. Aguilar-Ibarra, F. Micheli, and A. SáenzArroyo. 2016. Exploring the role of gender in common-pool resource extraction: evidence from laboratory and field experiments in fisheries. Applied Economics Letters 23: 912-920.

Sanchez-Bajo, C., and B. Roelants. 2011. Capital and the debt trap. learning from cooperatives in the global crisis. Houndmills/New York: Palgrave Macmillan.

SEMARNAT. 2012. Plan de Manejo Tipo Para Peces Marinos de Ornato. http://biblioteca.semarnat.gob.mx/janium/Documentos/Ciga/ libros2009/CD001354.pdf. Accessed 1 July 2019.

Teh, L.C.L., and U.R. Sumaila. 2013. Contribution of marine fisheries to worldwide employment. Fish and Fisheries 14: 77-88.

Torre, J., and F. Fernández Rivera-Melo. 2018. Acción sin daño: un análisis de las intervenciones de una organización de la sociedad civil ambientalista en comunidades costeras del Noroeste de México. Relaciones Estudios de Historia y Sociedad 39: 69-97.

UN Women. 2014. Gender equality capacity assessment tool. http://www. unwomen.org//media/headquarters/attachments/sections/library/ publications/2014/capacity assessmenttool_may2014_seconddraft pdf.pdf?la=en. Accessed 25 Abr 2019.

Woolley, A.W., C.F. Chabris, A. Pentland, N. Hashmi, and T.W. Malone. 2010. Evidence for a collective intelligence factor in the performance of human groups. Science 330: 686-688.

World Bank. 2012. Hidden harvest. The global contribution of capture fisheries. Washington, D.C.

Publisher's note Springer Nature remains neutral with regard to jurisdictional claims in published maps and institutional affiliations. 